\title{
ANALISIS FAKTOR-FAKTOR YANG MEMPENGARUHI PRODUKSI USAHATANI PADI SAWAH DI DESA TUMANI KECAMATAN MAESAAN
}

\author{
Friska Erika Moonik \\ Rine Kaunang \\ Tommy Fredy Lolowang
}

\begin{tabular}{ll}
\hline Naskah diterima melalui Website Jurnal Ilmiah agrisosioekonomi@ unsrat.ac.id & : Rabu, 18 Desember 2019 \\
Disetujui diterbitkan & : Kamis, 09 Januari 2020 \\
\hline
\end{tabular}

\begin{abstract}
This study aims to determine the effect of the use of land production factors, labor, seeds, urea and phonska fertilizers, as well as pesticides on the production of lowland rice farming in Tumani Village, Maesaan Sub-district. This research was conducted for two months from July to August 2019. The method of sampling used simple random sampling method. Data is collected by collecting primary data and secondary data. Primary data were obtained directly from 50 farmers as respondents through interviews with the help of a questionnaire while secondary data were obtained by searching documents from the Department of Agriculture. Analysis of the data used is the Cobb Douglas model regression analysis to see the effect of each production factor on the production produced. The results showed that, the variable area of land, seeds, phonska and labor had a significant effect, while the variable urea fertilizer and pesticides had no significant effect on the production of lowland rice in Tumani Village, Maustic District. ${ }^{*}$ eprm*
\end{abstract}

Keywords: lowland rice farming, influence, factors of production,

\begin{abstract}
ABSTRAK
Penelitian ini bertujuan untuk mengetahui pengaruh penggunaan faktor-faktor produksi tanah, tenaga kerja, benih, pupuk urea dan phonska, serta pestisida terhadap produksi usahatani padi sawah di Desa Tumani Kecamatan Maesaan. Penelitian ini dilaksanakan selama dua bulan dari bulan Juli sampai bulan Agustus tahun 2019. Cara pengambilan sampel menggunakan metode pengambilan sampel acak sederhana (simple random sampling). Pengambilan data dilakukan dengan mengumpulkan data primer dan data sekunder. Data primer didapat secara langsung dari 50 petani sebagai responden melalui wawancara dengan bantuan kuesioner sedangkan data sekunder diperoleh dengan penelusuran dokumen dari Dinas Pertanian. Analisis data yang digunakan adalah analisis regresi model Cobb Douglas untuk melihat pengaruh masing-masing faktor produksi terhadap produksi yang dihasilkan. Hasil penelitian menunjukkan bahwa, variabel luas lahan, benih, phonska dan tenaga kerja berpengaruh signifikan, sedangkan variabel pupuk urea, dan pestisida berpengaruh tidak signifikan terhadap produksi padi sawah di Desa Tumani Kecamatan Maesaan. ${ }^{*}{ }^{2}{ }^{*}$
\end{abstract}

Kata kunci: usahatani padi sawah, pengaruh, faktor-faktor produksi

Agrisosioekonomi: 


\section{PENDAHULUAN}

\section{Latar Belakang}

Indonesia merupakan negara agraris hal itu menjadikan sektor pertanian memiliki peranan penting pada perekonomian nasional. Hal ini dapat dilihat dari banyaknya penduduk atau tenaga kerja yang bekerja pada sektor pertanian atau dari produk yang berasal dari pertanian. Sektor pertanian memberikan kontribusi yang cukup besar terhadap pendapatan nasional Indonesia dan sebagian ekspor Indonesia berasal dari sektor pertanian, sehingga sektor pertanian mempunyai peranan penting dalam penyerapan tenaga kerja dan penyediaan kebutuhan pangan dan sandang bagi penduduk (Yuniarto, 2008).

Pembangunan pertanian khususnya pada subsektor tanaman pangan menjadi prioritas dalam pembangunan nasional sejak dikeluarkan revitalisasi pertanian. Sri Rejeki (2006) dalam Warsana (2007) menyatakan bahwa pembangunan pertanian masih berada diposisi yang strategis karena dianggap sebagai: (1) katalisator pembangunan, artinya sektor pertanian dapat menutupi kekurangan perekonomian agar tidak negatif, karena sektor ini dianggap lebih bertahan dibanding dengan sektor lain; (2) stabilisator harga dalam perekonomian, karena hasil tanaman pertanian terutama tanaman bahan pangan merupakan kebutuhan pokok masyarakat, sehingga dengan menjaga kestabilan harga bahan pokok, maka harga barang lain juga akan menjadi stabil; (3) sebagai sumber devisa non-migas, harga barang non-migas terutama hasil pertanian lebih stabil dibandingkan dengan harga migas.

Proses produksinya sektor pertanian memerlukan berbagai jenis masukan (input), masukan tersebut menghasilkan keluaran (output) yang dapat dijadikan masukan bagi sektor lain seperti sektor industri. Proses produksi pertanian bisa berjalan bila persyaratan faktor produksi yang dibutuhkan telah terpenuhi. Faktor produksi dapat terdiri dari beberapa komponen seperti tanah, modal, tenaga kerja, dan skill atau manajemen (pengelolaan). Dalam beberapa literatur, sebagian para ahli mencamtukan hanya tiga faktor produksi, yaitu tanah, modal, dan tenaga kerja. Masingmasing faktor mempunyai fungsi yang berbeda dan saling terkait satu sama lain. Jika salah satu faktor tidak tersedia maka proses produksi tidak akan berjalan (Daniel, 2002).
Salah satu komoditas pertanian yang diharapkan dapat bergerak positif dalam hal peningkatan produksi dan pendapatannya adalah padi. Beberapa alasan penting keberlanjutan produksi padi perlu dijaga yaitu: (a) beras merupakan bahan pangan pokok bagi masyarakat Indonesia, (b) merupakan komoditas penting untuk menjaga ketahanan pangan, (c) usahatani padi sudah merupakan bagian hidup dari petani Indonesia sehingga menciptakan lapangan kerja yang besar, (d) kontribusi dari usahatani padi terhadap pendapatan rumah tangga cukup besar (Hamdhan, 2013).

Optimasi produktivitas padi di lahan sawah merupakan salah satu peluang peningkatan produksi gabah nasional. Belum optimalnya produktivitas padi di lahan sawah, antara lain disebabkan oleh; a) rendahnya efisiensi pemupukan; b) belum efektifnya pengendalian hama penyakit; c) penggunaan benih, pupuk dan pestisida yang kurang bermutu dan varietas yang dipilih kurang adaptif; d) sifat fisik tanah tidak optimal (Makarim et al., 2000 dalam Mafor, 2015).

Kecamatan Maesaan merupakan salah satu daerah yang memiliki potensi pertanian khususnya komoditi tanaman pangan dan holtikultura.

Tabel 1. Komoditi Tanaman Pangan dan Holtikultura di Kecamatan Maesaan

\begin{tabular}{clccc}
\hline No & $\begin{array}{c}\text { Jenis } \\
\text { Komoditi }\end{array}$ & $\begin{array}{c}\text { Luas } \\
\text { Tanam } \\
\text { (Ha) }\end{array}$ & $\begin{array}{c}\text { Luas } \\
\text { Panen } \\
\text { (Ha) }\end{array}$ & $\begin{array}{c}\text { Produksi } \\
\text { (Ton) }\end{array}$ \\
\hline 1 & Padi Sawah & 2482 & 2482 & 5,3 \\
2 & Jagung & 920 & 920 & 4,9 \\
3 & Ubi Kayu & 20 & 20 & 8 \\
4 & Ubi Jalar & 10 & 10 & 4 \\
5 & Kedele & 75 & 75 & 1,2 \\
6 & Kacang Tanah & 90 & 90 & 1,7 \\
7 & Kacang Hijau & 3 & 3 & 1,1 \\
8 & Kacang Merah & 3 & 3 & 1,5 \\
9 & Cabe & 20 & 20 & 3,5 \\
\hline
\end{tabular}

Tabel 1 menunjukkan bahwa komoditi padi sawah merupakan komoditi yang paling banyak diusahakan oleh petani yang ada di Kecamatan Maesaan. Desa Tumani merupakan salah satu desa yang berada di Kecamatan Maesaan, sebagian besar masyarakat yang ada di desa ini bermata pencaharian sebagai petani. Luas areal sawah di desa Tumani adalah sekitar 102,8 ha, menjadikan padi sawah sebagai komoditi pertanian yang paling banyak diusahakan oleh petani yang ada di desa Tumani. 
Upaya petani kentang dalam mendapatkan keuntungan dan produksi yang maksimal, maka petani harus mengetahui faktor-faktor apa yang dapat mempengaruhi produksi. Karena itulah perlu dilakukan penelitian tentang pengaruh penggunaan faktor-faktor produksi pada usahatani padi sawah di Desa Tumani Kecamatan Maesaan.

\section{Rumusan Masalah}

Berdasarkan penjelasan di atas, maka yang menjadi rumusan masalah dalam penelitian ini adalah bagaimana pengaruh penggunaan faktorfaktor produksi yaitu tanah/lahan, tenaga kerja, benih, pupuk urea dan phonska, serta pestisida pada usahatani padi sawah di Desa Tumani Kecamatan Maesaan.

\section{Tujuan Penelitian}

Penelitian ini bertujuan untuk mengetahui pengaruh penggunaan tanah/lahan, tenaga kerja, benih, pupuk urea dan phonska, serta pestisida pada usahatani padi sawah di Desa Tumani Kecamatan Maesaan.

\section{Manfaat Penelitian}

Manfaat dari penelitian ini adalah memberikan informasi kepada petani padi sawah di daerah penelitian agar dapat mengolah usahatani dengan menggunakan faktor produksi secara tepat demi meningkatkan produksi padi juga sebagai bahan informasi bagi peneliti selanjutnya.

\section{METODE PENELITIAN}

\section{Tempat dan Waktu Penelitian}

Penelitian ini dilaksanakan di Desa Tumani Kecamatan Maesaan Kabupaten Minahasa Selatan. Lokasi tersebut dipilih karena merupakan salah satu daerah penghasil Padi (Beras) di Kabupaten Minahasa Selatan. Kegiatan penelitian akan dilakukan selama 2 bulan mulai dari bulan Juli hingga Agustus 2019 mulai dari persiapan pengambilan data sampai pada penyusunan laporan hasil penelitian.

\section{Metode Pengumpulan Data}

Dengan mengumpulkan data primer dan data sekunder, penelitian dilakukan secara terstruktur. Data primer didapat secara langsung dari petani melalui interview (wawancara) dan kuesioner sedangkan data sekunder diperoleh dengan penelusuran berupa dokumen dari Dinas Pertanian ataupun instansi terkait. Dan juga dari internet, sumber pustaka atau literatur (buku, jurnal dan karya ilmiah) yang relevan dengan topik penelitian.

\section{Metode Pengambilan Sampel}

Menggunakan simple random sampling (sampel acak sederhana). Di Desa Tumani Kecamatan Maesaan terdapat 145 petani. Sampel yang diambil adalah sebanyak 50 petani padi sawah.

\section{Konsep dan Pengukuran Variabel}

Variabel-variabel bebas/independen(X) adalah luas lahan, tenaga kerja, benih, pupuk dan pestisida sedangkan untuk variabel dependen/terikat (Y) yang digunakan adalah jumlah produksi.

Masing-masing variabel tersebut dapat dijelaskan sebagai berikut:

1. Jumlah hasil produksi adalah seluruh total produksi padi yang dihasilkan oleh setiap petani selama satu musim tanam dengan menggunakan seluruh faktor - faktor produksi yang tersedia. Hasil produksi GKG diukur dalam satuan Kilogram $(\mathrm{Kg})$.

2. Luas lahan adalah luas lahan produksi atau area pertanian yang digunakan oleh petani untuk menghasilkan padi yang diukur dalam hektar (Ha).

3. Jumlah benih adalah jumlah benih yang digunakan dalam satu kali musim tanam diukur dalam satuan Kilogram $(\mathrm{Kg}) / \mathrm{Ha}$.

4. Pupuk urea adalah banyaknya pupuk urea yang digunakan dalam usaha tani padi yang diukur dalam satuan Kilogram $(\mathrm{Kg}) / \mathrm{Ha}$.

5. Pupuk phonska adalah banyaknya pupuk phonska yang digunakan dalam usaha tani padi yang diukur dalam satuan Kilogram $(\mathrm{Kg}) / \mathrm{Ha}$.

6. Pestisida adalah seluruh jumlah pestisida atau obat-obatan yang digunakan dalam usaha tani padi yang diukur dalam satuan Liter (Ltr)/Ha.

7. Tenaga kerja adalah seluruh jumlah tenaga kerja yang digunakan dalam masa penanaman atau produksi baik tenaga kerja keluarga maupun tenaga kerja sewa. Penggunaan tenaga kerja diukur dalam jumlah tenaga kerja $(\mathrm{HOK}) / \mathrm{Ha}$. 


\section{Metode Analisis Data}

\section{Analisis Regresi Model Fungsi Cobb Douglas}

Metode yang digunakan dalam penelitian ini untuk menganalisis faktor-faktor yang mempengaruhi produksi padi sawah di Desa Tumani Kecamatan Maesaan adalah analisis regresi model fungsi produksi Cobb-Douglas yaitu metode yang digunakan untuk mengetahui besarnya pengaruh perubahan dari suatu variabel independen terhadap variabel dependen.

Bentuk ekonometrik:

$$
Y=\beta_{0} \cdot X_{1}^{\beta 1} \cdot X_{2}^{\beta 2} \cdot X_{3}^{\beta 3} \cdot X_{4}^{\beta 4} \cdot X_{5}^{\beta 5} \cdot X_{6}{ }^{\beta 6} \cdot E
$$

Untuk mempermudahkan perhitungan, fungsi tersebut kemudian diubah dalam bentuk logaritma, sehingga persamaan matematisnya menjadi:

$$
\operatorname{Ln} Y=\ln \beta_{0}+\beta_{1} \ln X_{1}+\beta_{2} \ln X_{2}+\beta_{3} \ln X_{3}+\beta_{4} \ln X_{4}+\beta_{5} \ln X_{5}+\beta_{6} \ln X_{6}+\ln \varepsilon
$$

Keterangan:

$$
\begin{aligned}
\mathrm{Y} & =\text { Produksi }(\mathrm{Kg}) \\
\mathrm{X}_{1} & =\text { Luas Lahan }(\mathrm{Ha}) \\
\mathrm{X}_{2} & =\text { Jumlah Benih }(\mathrm{Kg}) \\
\mathrm{X}_{3} & =\text { Jumlah Pupuk Urea }(\mathrm{Kg}) \\
\mathrm{X}_{4} & =\text { Jumlah Pupuk Phonska }(\mathrm{Kg}) \\
\mathrm{X}_{5} & =\text { Jumlah Pestisida }(\mathrm{Ltr}) \\
\mathrm{X}_{6} & =\text { Jumlah Tenaga Kerja (HOK) } \\
\beta_{1}, \beta_{2}, \beta_{3}, \beta_{4}, \beta_{5}, \beta_{6}=\text { Koefisien regresi luas } & \text { lahan, TK, pupuk, benih, } \\
& \quad \text { pestisida } \\
\varepsilon & \text { Residual / faktor-faktor lain yang } \\
& \text { berpengaruh yang tidak dimasukkan } \\
& \text { dalam model }
\end{aligned}
$$

\section{HASIL DAN PEMBAHASAN}

\section{Deskripsi Wilayah Penelitian}

Desa Tumani merupakan desa yang terletak di Kecamatan Maesaan Kabupaten Minahasa Selatan Provinsi Sulawesi Utara. Adapun batasan-batasan wilayah desa Tumani adalah sebagai berikut :

$\begin{array}{ll}\text { Sebelah Timur } & \text { : Desa Kinalawiran } \\ \text { Sebelah Barat } & \text { : Desa Lowian } \\ \text { Sebelah Utara } & \text { : Desa Tumani Utara } \\ \text { Sebelah Selatan } & \text { : Desa Tumani Selatan }\end{array}$

Desa Tumani terletak 441 meter diatas permukaan laut. Luas wilayah Desa Tumani adalah 120 ha, yang terdiri dari 6 Jaga. Dengan jumlah penduduk 1.054 jiwa yang terdiri dari 515 laki -laki dan 539 perempuan, jumlah kepala keluarga 316 kk. Penduduk Desa Tumani sebagian besar beragama Kristen Protestan selebihnya beragama Islam dan Katolik. Desa Tumani menyediakan sarana dan prasarana pendidikan yaitu dua gedung sekolah dasar, dan satu gedung Taman Kanakkanak (TK).

\section{Karakteristik Petani Responden}

\section{Umur Petani}

Umur petani memiliki hubungan dengan kemampuan petani dalam bekerja. Dari segi fisik, semakin tua seseorang atau ketika melewati batas umur tertentu akan berkurang kemampuannya dalam bekerja. Umur petani responden dapat dilihat pada Tabel 2.

\section{Tabel 2. Jumlah Petani Responden Menurut} Kelompok Umur

\begin{tabular}{ccc}
\hline Umur (Tahun) & Jumlah (Orang) & Persentase (\%) \\
\hline $30-35$ & 1 & 2 \\
$36-41$ & 2 & 4 \\
$42-47$ & 10 & 20 \\
$48-53$ & 13 & 26 \\
$54-59$ & 7 & 14 \\
$60-65$ & 9 & 18 \\
$>66$ & 8 & 16 \\
\hline Jumlah & $\mathbf{5 0}$ & $\mathbf{1 0 0}$
\end{tabular}

Sumber: Diolah dari data primer 2019

Tabel 2 menunjukkan bahwa jumlah responden terbanyak ada pada kelompok umur 48-53 sebanyak 13 responden atau $26 \%$ dari total responden, diikuti oleh kelompok umur 42-47 sebanyak 10 responden atau $20 \%$, kemudian kelompok umur 60-65 berjumlah 9 responden atau $16 \%$, kelompok umur $>66$ sebanyak 8 responden atau 16\%, kelompok umur 54-59 sebanyak 7 responden atau 14\%, kelompok umur 36-41 sebanyak 2 responden atau $4 \%$ dan kelompok umur 30-35 sebanyak 1 responden atau $2 \%$.

\section{Tingkat Pendidikan}

Tingkat pendidikan merupakan salah satu indikator keadaan sosial ekonomi masyarakat dan faktor yang penting dalam usaha peningkatan kualitas sumber daya manusia, semakin tinggi tingkat pendidikan seseorang akan mempengaruhi cara berpikir atau menerima suatu inovasi. Berdasarkan hasil penelitian tingkat pendidikan petani responden dapat dilihat pada Tabel 3 . 
Tabel 3. Jumlah Petani Responden Menurut Tingkat Pendidikan

\begin{tabular}{lcc}
\hline $\begin{array}{c}\text { Tingkat } \\
\text { Pendidikan }\end{array}$ & Jumlah (Orang) & $\begin{array}{c}\text { Persentase } \\
(\boldsymbol{\%})\end{array}$ \\
\hline SD & 8 & 16 \\
SMP & 20 & 40 \\
SMA & 22 & 44 \\
\hline \multicolumn{1}{c}{ Jumlah } & $\mathbf{5 0}$ & $\mathbf{1 0 0}$ \\
\hline
\end{tabular}

Sumber: Diolah dari data primer 2019

Tabel 3 menunjukkan bahwa tingkat pendidikan dengan jumlah responden terbanyak yaitu tinggkat pendidikan SMA dengan jumlah 22 responden atau $44 \%$, diikuti dengan tingkat pendidikan SMP dengan jumlah 20 responden atau $40 \%$ dan tingkat pendidikan SD dengan jumlah 8 responden atau $16 \%$.

\section{Jumlah Tanggungan Keluarga}

Jumlah tanggungan terdiri dari petani itu sendiri, istri, anak dan anggota keluarga lain yang termasuk dalam tanggungan petani. Keluarga petani dapat menjadi sumber tenaga kerja dalam usahatani. Jumlah petani responden berdasarkan tanggungan keluarga dapat dilihat pada Tabel 4.

Tabel 4. Jumlah Petani Responden Menurut Jumlah Tanggungan Keluarga

\begin{tabular}{ccc}
\hline $\begin{array}{c}\text { Jumlah Tanggungan } \\
\text { (Orang) }\end{array}$ & $\begin{array}{c}\text { Jumlah } \\
\text { (Orang) }\end{array}$ & $\begin{array}{c}\text { Persentase } \\
(\boldsymbol{\%})\end{array}$ \\
\hline $1-2$ & 16 & $32 \%$ \\
$3-4$ & 29 & $58 \%$ \\
$>5$ & 5 & $10 \%$ \\
\hline Jumlah & $\mathbf{5 0}$ & $\mathbf{1 0 0}$ \\
\hline
\end{tabular}

Sumber: Diolah dari data primer 2019

Tabel 4 menunjukkan bahwa jumlah tanggungan keluarga terbanyak adalah 3-4 dengan jumlah 29 responden atau 58\%, diikuti jumlah tanggungan keluarga 1-2 sebanyak 16 responden atau $32 \%$ dan jumlah tanggungan keluarga $>5$ sebanyak 5 responden atau $10 \%$.

\section{Pengalaman Bertani}

Pengalaman bertani merupakan salah satu faktor yang berpengaruh terhadap keberhasilan usahatani. Pengalaman kerja yang lebih lama dapat membuat petani memiliki kemampuan dalam usahatani dibandingkan dengan yang kurang berpengalaman. Untuk melihat jumlah petani berdasarkan pengalaman bertani dapat dilihat pada Tabel 5 .
Tabel 5. Jumlah Petani Responden Menurut Pengalaman Bertani di Desa Tumani

\begin{tabular}{ccc}
\hline $\begin{array}{c}\text { Pengalaman } \\
\text { Bertani (Tahun) }\end{array}$ & Jumlah (Orang) & $\begin{array}{c}\text { Persentase } \\
(\mathbf{\%})\end{array}$ \\
\hline $8-17$ & 5 & 10 \\
$18-27$ & 20 & 40 \\
$28-36$ & 9 & 18 \\
$37-45$ & 7 & 14 \\
$46-55$ & 9 & 18 \\
\hline Jumlah & $\mathbf{5 0}$ & $\mathbf{1 0 0}$ \\
\hline Sumber: Diolah dari data primer 2019 &
\end{tabular}

Tabel 5 menunjukkan bahwa jumlah petani responden berdasarkan pengalaman bertani terbanyak ada pada interval 18-27 tahun dengan jumlah 20 responden atau $40 \%$, untuk interval 28-36 tahun dan 46-55 tahun sama-sama berjumlah 9 responden, keduanya memiliki persentase $18 \%$, diikuti $37-45$ tahun sebanyak 7 responden dengan persentase $14 \%$ dan interval 8-17 berjumlah 5 responden dengan persentase $10 \%$.

\section{Luas Lahan}

Luas lahan yang diolah petani sangat menentukan besar kecilnya hasil produksi. Semakin luas lahan maka hasil produksi semakin bertambah begitupun sebaliknya semakin sempit lahan maka semakin sedikit produksi yang didapatkan. Luas lahan petani responden bervariasi 0.5 hektar sampai 5 hektar. Jumlah petani responden berdasarkan luas lahan dapat dilihat pada Tabel 6 .

\begin{tabular}{ccc}
\multicolumn{2}{c}{ Tabel 6. Luas Lahan Petani Responden } \\
\hline Luas Lahan (Ha) & Jumlah (Orang) & Persentase (\%) \\
\hline $0.01-0.99$ & 18 & 36 \\
$1-1.99$ & 21 & 42 \\
$2-3.99$ & 9 & 18 \\
$>4$ & 2 & 4 \\
\hline Jumlah & $\mathbf{5 0}$ & $\mathbf{1 0 0}$ \\
\hline Sumber: Diolah dari data primer 2019 &
\end{tabular}

Tabel 6 menunjukkan bahwa luas lahan yang paling banyak diolah petani adalah 1-1.99 hektar dengan jumlah 21 responden atau 42\%, diikuti luas lahan 0.01-0.99 hektar sebanyak 18 responden atau 36\%, luas lahan 2-3.99 hektar sebanyak 9 responden, dan $>4$ hektar sebanyak 2 responden atau $4 \%$.

\section{Analisis Regresi}

Berdasarkan hasil estimasi diatas maka fungsi produksi padi sawah diduga sebagai berikut: $\mathrm{Y}=8.38+0.984 \operatorname{Ln} \mathrm{X} 1+0.228 \operatorname{Ln} \mathrm{X} 2-0.0777 \operatorname{Ln} \mathrm{X} 3+0.0483 \operatorname{Ln} \mathrm{X} 4-0.0848 \operatorname{Ln} \mathrm{X} 5+$ $0.0310 \mathrm{LnX} 6$ 
Nilai intersep/konstanta sebesar 8,38 pada fungsi produksi padi menyatakan bahwa apabila variabel independen dianggap konstan maka output produksi akan bertambah senilai 8.38. Selain konstanta pada persamaan regresi juga terdapat koefisien dari masing-masing variable. Koefisien ini akan menentukan nilai variable jika terjadi perubahan, output analisis regresi dapat dilihat pada Tabel 7.

Tabel 7. Output Analisis Regresi

\begin{tabular}{lcccc}
\hline \multicolumn{1}{c}{ Predictor } & Coef & SE Coef & T & P \\
\hline Constant & 8.3796 & 0.4165 & 20.12 & 0.000 \\
Ln Luas Lahan & 0.98399 & 0.01581 & 62.23 & 0.000 \\
Ln Benih & 0.22831 & 0.05887 & 3.88 & 0.000 \\
Ln Urea & -0.07774 & 0.07495 & -1.04 & 0.305 \\
Ln Phonska & 0.04829 & 0.07196 & 0.67 & 0.506 \\
Ln Pestisida & -0.08479 & 0.04045 & -2.10 & 0.42 \\
Ln TK & 0.03102 & 0.02269 & 1.37 & 0.179 \\
Sumber: Diolah dari data primer 2019 & & &
\end{tabular}

\section{Analisis Faktor-Faktor yang Mempengaruhi Produksi}

Hasil pendugaan pada fungsi CobbDouglas akan menghasilkan koefisien regresi. Jadi besarnya b1 dan b2 adalah angka elastisitas. Jumlah dari elastisitas adalah merupakan ukuran return to scale.

Tabel 8. Nilai Elastisitas Faktor-Faktor Produksi pada Fungsi

\begin{tabular}{lc}
\multicolumn{2}{c}{ Produksi Padi Sawah } \\
\hline \multicolumn{1}{c}{ Faktor Produksi } & $\begin{array}{c}\text { Nilai Elastisitas Produksi } \\
\text { (Ep) }\end{array}$ \\
\hline Luas Lahan & 0.984 \\
Benih & 0.228 \\
Urea & -0.421 \\
Phonska & 0.0483 \\
Pestisida & -0.0848 \\
Tenaga Kerja & 0.031 \\
Sumber: Diolah dari data primer 2019
\end{tabular}

\section{Pengaruh Luas Lahan Terhadap Produksi}

Berdasarkan hasil perhitungan Nilai koefiesien luas lahan bertanda positif dengan nilai sebesar 0.984 artinya setiap penambahan 1 persen luas lahan maka produksi akan meningkat sebesar 0.984 persen, dengan asumsi variabel-variabel lain bersifat konstan. Dalam implikasinya luas lahan dapat langsung berpengaruh terhadap produksi padi sawah di Desa Tumani kecamatan Maesaan. Dengan demikian diperlukan kebijakan yang khusus terhadap luas lahan, karena dengan melakukan usahatani pada lahan yang luas maka akan semakin meningkatkan produksi.

\section{Pengaruh Benih Terhadap Produksi}

Nilai koefisien regresi benih sebesar 0.228 bernilai positif yang berarti setiap penambahan 1 persen bibit akan meningkatkan produksi padi sebesar 0.228 persen dengan asumsi variabel-variabel lain bersifat konstan. Berdasarkan hasil pengamatan diduga bahwa memungkinkan penambahan bibit karena ada jarak tanam yang belum efektif sehingga jika penambahan bibit diikuti dengan jarak tanam yang sesuai maka akan meningkatkan produksi.

3. Pengaruh Urea Terhadap Produksi

Nilai koefisien untuk variabel urea adalah -0.421 bernilai negatif yang menunjukkan adanya pengaruh yang berlawanan atau berbanding terbalik antara urea dengan jumlah produksi padi sawah. Dengan kata lain apabila ada penambahan urea sebesar 1 persen maka terjadi penurunan produksi padi sebesar 0.0421 persen. Koefisien regresi bernilai negatif diduga karena penggunaan pupuk urea sudah berlebihan. Hal ini dibuktikan dengan data bahwa rata-rata penggunaan pupuk urea per hektar di Desa Tumani Kecamatan Maesaan adalah $293.67 \mathrm{~kg} / \mathrm{Ha}$ melebihi dari dosis yang dianjurkan yaitu 250 $\mathrm{kg} / \mathrm{Ha}$.

4. Pengaruh Phonska Terhadap Produksi

Nilai koefisien regresi phonska sebesar 0.0483 dengan nilai signifikansi sebesar 0.506 bernilai positif yang berarti setiap penambahan 1 persen phonska maka akan meningkatkan produksi padi sebesar 0.0483 persen dengan asumsi variabel-variabel lain bersifat konstan.

\section{Pengaruh Pestisida Terhadap Produksi}

Nilai koefisien untuk variabel pestisida adalah -0.0848 bernilai negatif yang menunjukkan adanya pengaruh yang berlawanan atau berbanding terbalik antara pestisida dengan jumlah produksi padi sawah. Dengan kata lain apabila ada penambahan pestisida sebesar 1 persen maka terjadi penurunan produksi padi sebesar 0.0848 persen. Kegiatan pengendalian organisme pengganggu tanaman dalam usahatani padi sawah merupakan salah satu faktor penentu untuk memperoleh hasil yang diharapkan. Oleh karena itu jumlah dan aplikasi penyemprotan harus disesuaikan dengan kondisi dilapangan. Variabel pestisida bernilai negatif diduga disebabkan oleh tidak efektifnya penggunaan pestisida atau sudah melebihi dosis yang diperlukan oleh tanaman padi sawah. 


\section{Pengaruh Tenaga Kerja Terhadap Produksi}

Nilai koefisien untuk variabel tenaga kerja adalah 0.0310 bernilai positif yang berarti setiap penambahan 1 persen tenaga kerja maka akan meningkatkan produksi padi sebesar 0.0310 persen dengan asumsi variabel-variabel lain bersifat konstan. Dalam usahatani padi sawah curahan tenaga kerja efektif disesuaikan dengan kegiatan produksi yang meliputi pengolahan lahan, pembibitan, penanaman, pemeliharaan dan panen. Curahan tenaga kerja yang tepat akan memberikan dampak positif pada produksi padi. Berdasarkan pengamatan koefisien regresi tenaga kerja bernilai positif karena sebagian besar tenaga kerja yang digunakan berada pada usia produktif untuk bekerja.

\section{Skala Usaha}

Nilai return to scale dapat diketahui dengan cara menjumlahkan koefisien elastisitas dari faktor-faktor produksi. Jika hasil penjumlahan semua koefisien regresi tersebut kurang dari satu maka penambahan faktor produksi dalam jumlah yang sama akan menyebaabkan penurunan tambahan hasil produksi. Jika hasil penambahan semua koefisien regresi lebih dari satu maka penambahan faktor produksi dalam jumlah yang sama akan menyebabkan kenaikan dari tambahan hasil produksi. Dan jika penambahan semua koefisien tersebut sama dengan satu maka penambahan faktor produksi dalam jumlah yang sama tidak akan berpengaruh terhadap hasil produksi, karena tambahan hasil produksi adalah tetap.

Hasil penjumlahan dari seluruh koefisien adalah 0.7855 menunjukan hasil kurang dari satu, sehingga skala hasil produksi tanaman padi sawah di Desa Tumani Kecamatan Maesaan termasuk dalam decreasing return to scale. Yang berarti bahwa setiap penambahan input 1 persen akan meningkatkan produksi kurang dari 1 persen. Banyak faktor yang menyebabkan skala produksi dalam keadaan decreasing return to scale, diantaranya adalah : a. Pengelolaan atau manajemen yang buruk meliputi adanya pemupukan yang dilakukan tidak tepat waktu, pemupukan yang berlebihan, pemupukan yang kurang, penggunaan pestisida yang berlebihan serta penggunaan tenaga kerja yang tidak produktif.

b. Pada umunya pertanian di Desa Tumani hanya dikelola oleh keluarga dengan pengelolaan yang sederhana sehingga para petani tidak begitu memperhatikan efektifitas dan produktivitas usahanya dan ini berpengaruh terhadap produksi.

c. Faktor eksternal seperti cuaca yang tidak dapat diprediksi.

\section{KESIMPULAN DAN SARAN}

\section{Kesimpulan}

Hasil penelitian menunjukkan bahwa pengaruh faktor-faktor produksi luas lahan, benih, urea, phonska, pestisida dan tenaga kerja maka dapat disimpulkan bahwa variabel luas lahan, benih, phonska, dan tenaga kerja berpengaruh positif dan signifikan terhadap produksi padi di Desa Tumani, sedangkan variabel pupuk urea, dan pestisida berpengaruh negatif dan tidak signifikan terhadap produksi padi sawah di Desa Tumani, Kecamatan Maesaan.

\section{Saran}

Bagi petani agar dapat memperhitungkan dengan baik jumlah penggunaan urea dan pestisida karena sudah melebihi dosis yang dianjurkan agar tidak mengurangi produksi. Bagi Pemerintah diharapkan mampu memfasilitasi sarana dan prasarana yang lebih baik untuk petani agar mudah dalam mengakses informasi tentang penggunaan faktor-faktor produksi. Penyuluh pertanian diharapkan mampu menciptakan hubungan baik dengan para petani agar terjalin hubungan yang harmonis antara penyuluh dan petani yang dapat mengubah pola pikir petani untuk menerapkan teknologi yang lebih baik. 


\section{DAFTAR PUSTAKA}

Daniel, M. 2002. Pengantar Ilmu Ekonomi Pertanian. PT. Bumi Aksara. Jakarta.

Hamdhan. 2013. Analisis Efisiensi Penggunaan Faktor Produksi Pada Usahatani Padi Sawah di Bengkulu. Balai Pengkaji Teknologi Pertanian. Bengkulu.

Mafor, K. 2015. Analisis Faktor Produksi Padi Sawah di Desa Tompasobaru Dua Kecamatan Tompasobaru. UNSRAT. Manado.
Warsana. 2007. Analisis Efisiensi dan Keuntungan Usahatani Jagung (Studi Kasus di Kecamatan Randublatung Kabupaten Blora. UNDIP. Semarang.

Yuniarto. 2008. Analisis Faktor-Faktor Yang Mempengaruhi Produksi Bawang Merah Studi Kasus Desa Kendawa Kecamatan Jatibarang Kabupaten Brebes. UNDIP. Semarang. 